Arq. Bras. Med. Vet. Zootec., v.71, n.2, p.521-528, 2019

\title{
(+)-Catechin and (-)-epigallocatechin gallate: are these promising antioxidant therapies for frozen goat semen?
}

\author{
$[(+)$-Catequina e (-)-epigalocatequina galato: essas são promissoras terapias antioxidantes para a \\ congelação de sêmen caprino?]
}

\author{
E.C.B. Silva, L.C.P. Arruda, J.I.T. Vieira, P.C. Soares, M.M.P. Guerra
}

E.C.B. Silva https://orcid.org/0000-0001-8935-6553 L.C.P. Arruda https://orcid.org/0000-0002-5732-9777 J.I.T. Vieira https://ordid.org/0000-0001-8353-7898 P.C. Soares https://orcid.org/0000-0002-5680-3940 M.M.P. Guerra https://orcid.org/0000-0002-5373-4062

Universidade Federal Rural de Pernambuco - Recife, PE

\begin{abstract}
The aim of this study was to evaluate the effects of different concentrations of (+)-catechin or (-)epigallocatechin gallate (EGCG) on goat semen freezability. Poolsof semen were processed (Experiment 1: $0,15,25,50,75$, or $100 \mu \mathrm{M}(+)$-catechin; Experiment 2: 0, 15, 25, 50, 75, or $100 \mu \mathrm{M} \mathrm{EGCG)} \mathrm{and}$ frozen. After thawing, the samples were evaluated for kinematics, plasma membrane (PMi) and acrosome integrity, morphology, and oxidative stress, at 0 and $1 \mathrm{~h}$. In Experiment 1 , at $0 \mathrm{~h}$, VSL and VAP were greater $(\mathrm{P}<0.05)$ with $15 \mu \mathrm{M}$ than with 50 and 100 ; WOB was lower $(\mathrm{P}<0.05)$ with $100 \mu \mathrm{M}$ than with 0 , 15, and 25; and $\mathrm{BCF}$ was higher $(\mathrm{P}<0.05)$ with 75 and $100 \mu \mathrm{M}$ than with 0 . In turn, in Experiment 2, progressive motility was higher $(\mathrm{P}<0.05)$ with 0 and $15 \mu \mathrm{M}$ than with50 and 75 ; LIN was lower $(\mathrm{P}<0.05)$ with75 and $100 \mu \mathrm{M}$ than with0 and 15 ; WOB was higher $(\mathrm{P}<0.05)$ with0 and $15 \mu \mathrm{M}$; and PMi was greater $(\mathrm{P}<0.05)$ with $100 \mu \mathrm{M}$ than 0 . Thus, $(+)$-catechin or EGCG at higher concentrations inhibits the kinematics of frozen goat sperm, in a transitory way, and 100 $\mu$ M of EGCG preserves the PMi.
\end{abstract}

Keywords: antioxidants, cryopreservation, flavonoids, oxidative stress, semen

\section{RESUMO}

Objetivou-se avaliar o efeito de diferentes concentrações de (+)-catequina ou (-)-epigalocatequina galato (EGCG) sobre a congelabilidade do sêmen caprino. Poolsseminais foram processados

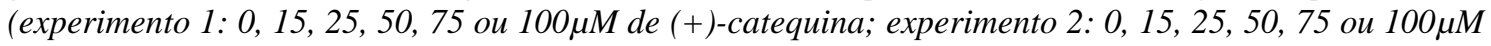
de EGCG) e congelados. Após a descongelação, foram avaliadas a cinética, a integridade de membrana plasmática (iMP) e acrossomal, a morfologia e o estresse oxidativo, a zero e a uma hora. No experimento 1 , a zero hora, VSL e VAP foram maiores $(P<0,05)$ com $15 \mu M$ do que com 50 e100; WOB foi menor

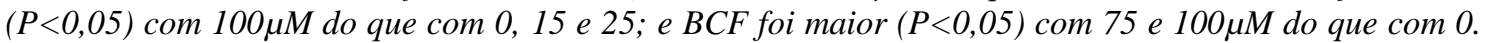
No experimento 2, a motilidade progressiva foi maior $(P<0,05)$ com 0 e $15 \mu M$ do que com 50 e 75 ; LIN

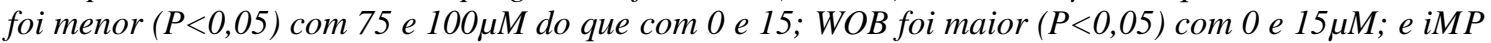
foi maior $(P<0,05)$ com 100 $\mu M$ do que com 0 . Assim, (+)-catequina ou EGCG em altas concentrações

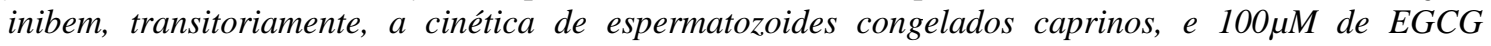
preserva a iMP.

Palavras-chave: antioxidantes, criopreservação, flavonoides, estresse oxidativo, sêmen

\section{INTRODUCTION}

The catechin isomers, (+)-catechin and epigallocatechin gallate (EGCG), are flavanols from the flavonoid family, found in plant-based foods and beverages (Weinreb et al., 2009; Li, 2011). Because of their chemical structures,

Recebido em 19 de janeiro de 2018

Aceito em 31 de agosto de 2018

E-mail: silva.ecb@gmail.com these phytochemical compounds are more powerful antioxidants than other agents (Weinreb et al., 2009). The protective effects of catechins occur throughhydrogen-donation, the regulatory effect on enzymatic antioxidant expression, inhibition of pro-oxidant enzymes,chelation of metallic ions (Li, 2011), and protection fromother antioxidants (Lotito and Fraga, 2000). 
Some of the beneficial effects of catechins in vitro and in vivo are antibacterial (Mabe et al., 1999), antiviral (Song et al., 2005), antifungal (Hirasawa and Takada, 2004), antitumor (Gu et al., 2013), and anti-obesity (Nagao et al., 2005) activities. Moreover, these flavanolsactas neuroprotectors (Weinreb et al., 2009; Nath et al., 2012) and protectors of testicular parenchyma (Ding et al., 2015)and sperm (Boonsorn et al., 2010; De Amicis et al., 2012).

Semen cryopreservation is a reproductive biotechnique that has an important role in the animal industry, contributing to the expansion of other reproductive techniques (Barbas and Mascarenhas, 2009), and intensifying the productive system and genetic improvement (Leboeuf et al., 2000). Nonetheless, during this process, especially during freezing-thawing, the sperm cell is frequently injured (Leboeuf et al., 2000 ), with consequent reductions in its viability and function (Bansal and Bilaspuri, 2011).

Among the factors related to sperm injuries generated during cryopreservation, the high production of reactive oxygen species (ROS) is noteworthy (Watson, 2000; Bansal and Bilaspuri, 2011). ROS have detrimental effects on biological molecules, especially lipids (Saleh and Agarwal, 2002). Thus, mammalian sperm cell membranes are susceptible to oxidants attack, once that are rich in polyunsaturated fatty acids (Bansal and Bilaspuri, 2011).Therefore, the aim of this study was to evaluate the effects of different concentrations of (+)-catechin or (-)epigallocatechin gallate on goat semen freezability.

\section{MATERIALS AND METHODS}

Except when specified, all reagents used in the experiment were obtained from Sigma-Aldrich Company (St Louis, MO, USA).

The experimental protocol was approved by the Ethics Committee for Animal Experimentation of the Federal Rural University of Pernambuco (UFRPE - Brazil), under process number CEUA/UFRPE 014/2012. Six mature and fertile goats (three Saanen, two Toggenburg, and one British Alpine), from one to fouryrsold, were used. The animals were raised at UFRPE, Pernambuco, Brazil (08 03' 14', S; 34 52' 52', $\mathrm{W})$, and fed with hay and commercial chow, as well as mineral salt and water ad libitum.
The semen was collected from six mature male goats, six times per experiment, at $48 \mathrm{~h}$ intervals, using an artificial vagina and a female as the dummy, totalling 72 ejaculates (36 ejaculates per experiment). Fresh semen samples were subjectively examined for mass movement (0-5), motility, and vigour ( 0 to $100 \%$ and 0 to 5 , respectively; magnification, 100x). Samples were also analysed in a Neubauer chamber for concentration $(400 \mathrm{x})$ and in a moist chamber for sperm morphology (1000x), after dilution in formol citrate solution (1:400; v:v), using phasecontrast microscopy (Olympus, Tokyo, Japan). Ejaculates collected on the same day from the six male goats and approved (mass movement $\geq 3$, motility $\geq 70 \%$, vigor $\geq 3$, concentration $\geq 2 \times 10^{9}$ sperm $/ \mathrm{ml}$, and total sperm pathologies $\leq 20 \%$ ) were pooled, totalling six pools $(\mathrm{n}=6)$ per experiment.

Each one of the six goat semen pools per experiment were diluted $(1: 9 ; \mathrm{v}: \mathrm{v})$ in Tris solution $\quad(3,605 \mathrm{~g} \quad$ Tris-hydroxymethyl aminomethane, 2,024g citric acid, 1,488g fructose and 100mlMilli-Q water, $\mathrm{pH}$ 6.8) and centrifuged (250 $\mathrm{X} \mathrm{g}$ for 10min) twice. Subsequently, semen samples were divided into six equal aliquots, and diluted with a skim milkbased extender [10g skim milk powder, 194mg D-(+)-glucose, 100mlMilli-Q water, $7 \%$ glycerol, $\mathrm{pH}$ 6.8] containing (+)-catechin or EGCG, according to the experiment or experimental groups (Experiment 1: 0, 15, 25, 50, 75, and 100 $\mu$ Mcatechin; Experiment 2: 0, 15, $25,50,75$, and $100 \mu \mathrm{M}$ EGCG).The final sperm concentration was $200 \times 10^{6} \mathrm{sperm} / \mathrm{ml}$.

Extended semen samples were packed into $0.25 \mathrm{ml}$ straws, and frozenusing an automated system $\quad\left(\mathrm{TK}-3000^{\circledR}\right.$, TK Tecnologia em congelação Ltd, Uberaba, Brazil), in a slow curve specific for goats. During the positive step, the temperature drop was $0.25^{\circ} \mathrm{C}$ per min until reaching $5^{\circ} \mathrm{C}$, at which temperature the samples were maintained for $120 \mathrm{~min}$ for stabilisation. The negative step was started with a temperature drop of $20^{\circ} \mathrm{C}$ per min until the temperature reached $-120^{\circ} \mathrm{C}$, when the straws were immersed and stored in liquid nitrogen $\left(-196^{\circ} \mathrm{C}\right)$. The $(+)-$ catechin and EGCG stock solutions (10mM) were prepared in DMSO and stored at $-20^{\circ} \mathrm{C}$.

After a minimum interval of $24 \mathrm{~h}$ of frozen storage, four straws per experimental group were 
thawed $\left(37^{\circ} \mathrm{C}\right.$ for $\left.30 \mathrm{~s}\right)$. Aliquots of semen were analysed after 0 and $1 \mathrm{~h}$ of incubation at $34^{\circ} \mathrm{C}$, according to the descriptions below. This procedure was repeated six times for each experiment and experimental group $(n=6)$.

For sperm kinematic analysis, aliquots of semen from each experimental group were diluted in a skim milk-based extender $(1: 4 ; \mathrm{v}: \mathrm{v})$ to reduce the sperm concentration $\left(50 \times 10^{6} \mathrm{sperm} / \mathrm{ml}\right)$ and facilitate the capture of images. The analysis was performed by placing $5 \mu 1$ of each sample on a previously heated slide $\left(37^{\circ} \mathrm{C}\right)$ and depositing a cover slip over the drop. The slide was placed under a phase-contrast microscope (Nikon $^{\mathrm{TM}}$ H5505, Eclipse 50i, Tokyo, Japan) and the images captured using a video camera (Basler Vision Tecnologie ${ }^{\mathrm{TM}}$ A312FC, Ahrensburg, Germany). Five non-consecutive, randomly selected microscopic fields per sample were scanned, recording at least 2000 sperm. The parameters assessed using the Sperm Class Analyzer - $\mathrm{SCA}^{\mathrm{TM}}$ software v. 5.1 (Microptics, S.L., Barcelona, Spain) were: total motility (TM, $\%$ ), progressive motility (PM, \%), curvilinear velocity (VCL, $\mu \mathrm{m} / \mathrm{s})$, straight linear velocity (VSL, $\mu \mathrm{m} / \mathrm{s}$ ), average path velocity (VAP, $\mu \mathrm{m} / \mathrm{s}$ ), linearity (LIN, \%), straightness (STR, \%), wobble (WOB, \%), amplitude of lateral movement of the head (ALH, $\mu \mathrm{m})$, and beat cross frequency $(\mathrm{BCF}, \mathrm{Hz})$. The values of the CASA system were measured for the goat species, with the following configurations: $37^{\circ} \mathrm{C}$ temperature, $100 \mathrm{x}$ magnification, number of images 25 , 25images per second,20 to $70 \mu \mathrm{m}^{2}$ particle area, VAP $10 \mu / \mathrm{s}<$ slow $<45 \mu / \mathrm{s}<$ medium $<75 \mu / \mathrm{s}$ rapid, progressivity $>80 \%$ of STR, circular $<50 \%$ LIN, connectivity 12,5 VAP points, 5 fields, 2000 sperms, $20 \%$ concentration.

Plasma membrane integrity assessment was determined using the double staining method with carboxyfluorescein diacetate (CFDA) and propidium iodide (PI), as described by Silva et al. (2012). Aliquots $(50 \mu 1)$ of semen were diluted in $150 \mu$ lTris solution containing $5 \mu \mathrm{l}$ CFDA $(0.46 \mathrm{mg} / \mathrm{ml}$ in DMSO $)$ and $20 \mu \mathrm{PI}(0.5 \mathrm{mg} / \mathrm{ml}$ in PBS), incubated for $10 \mathrm{~min}$ at $37^{\circ} \mathrm{C}$ and fixed with PBS containing $0.5 \%$ glutaraldehyde. Using DBP 485/20nm excitation and DBP 580 to 630$\mathrm{nm}$ emission filters, 200 cells were examined per slide in an epifluorescence microscope (Carl Zeiss, Göttingen, Germany) at a magnification of 400x. Green fluorescence was interpreted as an intact membrane and red fluorescence as a damaged membrane.

Acrosome integrity was analysed using fluorescein isothiocyanate-conjugated agglutinin (FITC-PNA) (Silva et al., 2012). Aliquots (10 $\mu 1)$ of semen were prepared for smearing and air dried. An aliquot of $30 \mu 1$ FITC-PNA working solution $(40 \mu \mathrm{g} / \mathrm{ml}$ in PBS) was placed on each slide to stain the cells, incubated in a moist chamber at $4^{\circ} \mathrm{C}$ for $20 \mathrm{~min}$, rinsed in PBS, and dried in the dark. At the time of assessment, $5 \mu 1$ of the mounting medium $(4.5 \mathrm{ml}$ glycerol, $0.5 \mathrm{ml}$ PBS, 5mg sodium azide, and $5 \mathrm{mg}$ pphenylenediamine) was placed on the slide and covered with a cover slip. A total of 200 sperm per slide were examined using an LP 515-nm emission and 450-490 BP nm excitation filter, in an epifluorescence microscope (Carl Zeiss, Göttingen, Germany; 1000x). Sperm were classified as having an intact acrosome when this region was stained with green fluorescent and ashaving a reacted acrosome when the green fluorescent was present in the sperm equatorial region or when it was absent from the head.

The moist chamber method was used for the analysis of sperm morphology (Oliveira and Silva, 2013). Using this method, semen samples were diluted in a formol citrate solution (1:5) and a $10 \mu \mathrm{l}$ aliquot was placed on the slide and covered with a cover slip. A total of 200 cells were analysed per slide using a phase-contrast microscope (Olympus, Tokyo, Japan; 1000x) and classified as morphologically normal or not.

The nitroblue tetrazolium (NBT) test was employed to study sperm oxidative stress as described by Saleh and Agarwal (2002). Semen samples were diluted $(1: 1 ; \mathrm{v}: \mathrm{v})$ in NBT solution $\left(0.1 \%\right.$ in PBS), incubated for $30 \mathrm{~min}$ at $37^{\circ} \mathrm{C}$ and for an additional $30 \mathrm{~min}$ at room temperature. Next, the samples were centrifuged $(250 \mathrm{X} g$ for $5 \mathrm{~min}$ ) and the pellets re-suspended in Tris solution. Aliquots $(10 \mu 1)$ were prepared for smearing and air dried. One hundred sperm were evaluated per slide in a phase-contrast microscope (Olympus, Tokyo, Japan; 1000x). Sperm were classified as positive oxidative stress when they presented formazan deposition in the sperm head and/or mid-piece and as negative oxidative stress when the formazan deposition was absent. 
The results were expressed as means and standard deviations (mean $\pm \mathrm{SD})$. Before statistical analyses, the percentage data were arcsine transformed.To detect differences among concentrations of $(+)$-catechin $(0,15,25,5075$, and $100 \mu \mathrm{M})$ or EGCG $(0,15,25,5075$, and $100 \mu \mathrm{M})$ and the times of evaluation $(0$ and $1 \mathrm{~h}$ after thawing) from each experiment, were used the one-way ANOVA test and Student-NewmanKeuls (SNK) multiple comparison test. Moreover, regression analysis was performed from semen parameters, according to antioxidant concentrations (linear, quadratic, and cubic effect). For all analyses, values were considered significant at $\mathrm{P}<0.05$. Data were analyzed using the GLM (General Linear Model) from the Statistical Analysis System (SAS, 2009), as repeated measures in time.

\section{RESULTS}

Regarding the sperm kinematics of the cryopreserved goat semen samples, in Experiment 1, immediately after semen thawing (0h; Table 1), VSL and VAP were higher ( $\mathrm{P}<$ $0.05)$ in $15 \mu \mathrm{M}$ than 50 and $100 \mu \mathrm{M}(+)$-catechin; WOB was higher $(\mathrm{P}<0.05)$ in 0,15 and $25 \mu \mathrm{M}$ than $100 \mu \mathrm{M}(+)$-catechin; and $\mathrm{BCF}$ was higher $(\mathrm{P}<0.05)$ in 25,75 and $100 \mu \mathrm{M}$ than $0 \mu \mathrm{M}(+)-$ catechin.

Similarly, in Experiment 2, at 0h after thawing (Table 2), a higher $(\mathrm{P}<0.05) \mathrm{PM}$ was observed in the control $(0 \mu \mathrm{M})$ and $15 \mu \mathrm{M}$ treatments than with 50 and $75 \mu \mathrm{M}$ EGCG; LIN was greater $(\mathrm{P}<$ $0.05)$ in the control group than the 75 and $100 \mu \mathrm{M}$ EGCG, as well as in the $15 \mu \mathrm{M}$ than in $100 \mu \mathrm{M}$ EGCG; and WOB was higher $(\mathrm{P}<0.05)$ in 0 and $15 \mu \mathrm{M}$ than in 50, 75 and $100 \mu \mathrm{M}$ EGCG.

Table 1. Kinematic parameters of goat semen frozen with different concentrations of $(+)$-catechin

\begin{tabular}{|c|c|c|c|c|c|c|c|c|c|c|}
\hline \multirow[b]{2}{*}{ Parameters } & \multirow[b]{2}{*}{ Time } & \multicolumn{6}{|c|}{ Concentrations of $(+)$-catechin } & \multirow{2}{*}{\multicolumn{3}{|c|}{$\frac{\text { Regression assay* }}{\mathrm{P}>\mathrm{F}}$}} \\
\hline & & $0 \mu \mathrm{M}$ & $15 \mu \mathrm{M}$ & $25 \mu \mathrm{M}$ & $50 \mu \mathrm{M}$ & $75 \mu \mathrm{M}$ & $100 \mu \mathrm{M}$ & & & \\
\hline TM & $\mathrm{Oh}$ & $68.2 \pm 7.0$ & $71.0 \pm 13.8$ & $71.2 \pm 9.4$ & $69.4 \pm 7.2$ & $67.2 \pm 10.3$ & $72.1 \pm 10.7$ & Ns & ns & Ns \\
\hline \multirow[t]{2}{*}{ PM } & $\mathrm{Oh}$ & $23.7 \pm 3.7$ & $27.7 \pm 4.1$ & $24.2 \pm 2.6$ & $21.8 \pm 2.3$ & $23.5 \pm 3.2$ & $21.2 \pm 4.6$ & Ns & ns & Ns \\
\hline & $1 \mathrm{~h}$ & $25.1 \pm 3.6$ & $23.3 \pm 9.6$ & $21.8 \pm 5.5$ & $23.1 \pm 8.8$ & $23.3 \pm 6.4$ & $21.0 \pm 12.2$ & Ns & ns & Ns \\
\hline VCL & $\mathrm{Oh}$ & $81.2 \pm 10.1$ & $86.0 \pm 4.6$ & $80.9 \pm 2.5$ & $75.7 \pm 7.0$ & $80.3 \pm 10.8$ & $77.4 \pm 8.1$ & Ns & ns & Ns \\
\hline VSL & $1 \mathrm{~h}$ & $42.4 \pm 4.0$ & $43.2 \pm 6.1$ & $41.5 \pm 7.2$ & $40.4 \pm 8.0$ & $41.3 \pm 2.4$ & $38.0 \pm 8.8$ & Ns & ns & Ns \\
\hline \multirow[t]{2}{*}{ VAP } & $\mathrm{Oh}$ & $55.4 \pm 7.2^{\mathrm{ab}}$ & $59.2 \pm 4.4^{\mathrm{a}}$ & $54.7 \pm 3.1^{\mathrm{ab}}$ & $49.3 \pm 2.6^{\mathrm{b}}$ & $52.2 \pm 6.3^{\mathrm{ab}}$ & $48.0 \pm 4.5^{\mathrm{b}}$ & 0.0012 & ns & Ns \\
\hline & $1 \mathrm{~h}$ & $52.2 \pm 4.6$ & $53.8 \pm 9.2$ & $52.4 \pm 9.1$ & $50.5 \pm 9.9$ & $51.4 \pm 5.2$ & $47.6 \pm 9.4$ & Ns & $\mathrm{ns}$ & $\mathrm{ns}$ \\
\hline \multirow[t]{2}{*}{ LIN } & $0 \mathrm{~h}$ & $51.4 \pm 2.9$ & $52.9 \pm 7.0$ & $51.3 \pm 3.9$ & $49.2 \pm 5.1$ & $49.9 \pm 4.7$ & $45.6 \pm 2.2$ & 0.0139 & $\mathrm{~ns}$ & $\mathrm{~ns}$ \\
\hline & $1 \mathrm{~h}$ & $54.5 \pm 5.0$ & $54.1 \pm 4.2$ & $54.2 \pm 7.2$ & $53.0 \pm 6.8$ & $52.8 \pm 4.9$ & $51.2 \pm 5.8$ & Ns & ns & $\mathrm{ns}$ \\
\hline \multirow[t]{2}{*}{ ALH } & $\mathrm{Oh}$ & $3.1 \pm 0.2$ & $3.2 \pm 0.2$ & $3.1 \pm 0.2$ & $3.1 \pm 0.3$ & $3.2 \pm 0.4$ & $3.3 \pm 0.2$ & ns & ns & $\mathrm{ns}$ \\
\hline & $1 \mathrm{~h}$ & $3.2 \pm 0.2$ & $3.2 \pm 0.4$ & $3.1 \pm 0.4$ & $3.1 \pm 0.5$ & $3.2 \pm 0.3$ & $3.2 \pm 0.3$ & ns & ns & $\mathrm{ns}$ \\
\hline \multirow[t]{2}{*}{$\mathrm{BCF}$} & $\mathrm{Oh}$ & $11.1 \pm 0.8^{\mathrm{c}}$ & $11.4 \pm 0.6^{\mathrm{abc}}$ & $11.3 \pm 0.4^{\mathrm{ab}}$ & $11.7 \pm 0.5^{\mathrm{abc}}$ & $12.4 \pm 0.5^{\mathrm{a}}$ & $12.2 \pm 0.8^{\mathrm{ab}}$ & 0.0003 & ns & $\mathrm{ns}$ \\
\hline & $1 \mathrm{~h}$ & $13.0 \pm 1.0$ & $12.8 \pm 1.2$ & $12.5 \pm 0.8$ & $13.2 \pm 0.9$ & $13.1 \pm 1.1$ & $13.4 \pm 1.3$ & ns & ns & $\mathrm{ns}$ \\
\hline
\end{tabular}

Different letters in the same line denote significant differences between groups $(\mathrm{P}<0.05)$. TM: total motility $(\%)$; PM: progressive motility $(\%)$; VCL: curvilinear velocity $(\mu \mathrm{m} / \mathrm{s})$; VSL: straight linear velocity $(\mu \mathrm{m} / \mathrm{s})$; VAP: average path velocity $(\mu \mathrm{m} / \mathrm{s})$; LIN: linearity (\%); STR: straightness (\%); WOB: wobble (\%); ALH: amplitude of lateral movement of sperm head $(\mu \mathrm{m})$; BCF: beat cross frequency $(\mathrm{Hz})$. *L: linear; Q: quadratic; C: cubic.

No differences $(\mathrm{P}>0.05)$ were observed between the experimental groups related to the other kinematic parameters analysed at $0 \mathrm{~h}$, or those analysed at $1 \mathrm{~h}$ of incubation, in both experiments (Table 1 and 2). In addition, in Experiment 1, no differences $(\mathrm{P}<0.05)$ were observed in plasma membrane and acrosome integrity, percentage of morphologically normal sperm, and sperm without oxidative stress between the experimental groups, independent of the time of evaluation $(0$ and $1 \mathrm{~h})$ after semen thawing (Table 3 ). In Experiment 2 (Table 4), the percentage of sperm cells with intact plasma membrane was higher $(\mathrm{P}<0.05)$ in $100 \mu \mathrm{M}$ than in $0 \mu \mathrm{M}$ EGCG at $0 \mathrm{~h}$, but no statistical difference $(\mathrm{P}>0.05)$ was observed for the other parameters at 0 and $1 \mathrm{~h}$ of incubation. 
(+)-Catechin and...

Table 2. Kinematic parameters of goat semen frozen with different concentrations of EGCG

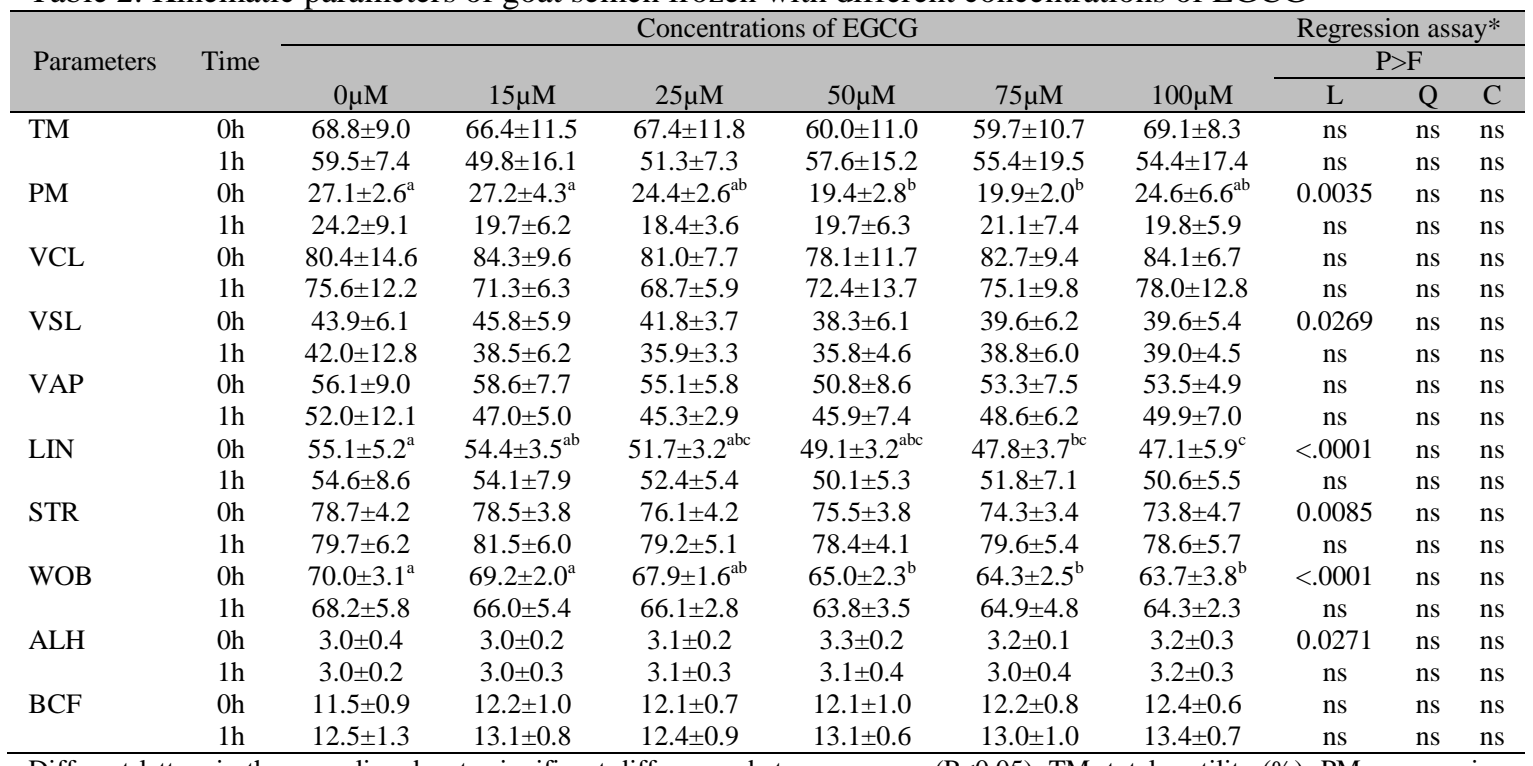

Different letters in the same line denote significant differences between groups $(\mathrm{P}<0.05)$. TM: total motility $(\%)$; PM: progressive motility $(\%)$; VCL: curvilinear velocity $(\mu \mathrm{m} / \mathrm{s})$; VSL: straight linear velocity $(\mu \mathrm{m} / \mathrm{s})$; VAP: average path velocity $(\mu \mathrm{m} / \mathrm{s})$; LIN: linearity (\%); STR: straightness (\%); WOB: wobble (\%); ALH: amplitude of lateral movement of sperm head $(\mu \mathrm{m})$; BCF: beat cross frequency $(\mathrm{Hz})$. *L: linear; Q: quadratic; C: cubic.

According to the regression analysis, higher concentrations of $(+)$-catechin resulted in lower values of VSL, VAP, LIN, and WOB, as well as higher values of $\mathrm{BCF}$ at $\mathrm{Oh}$ (Table 1). Likewise, higher concentrations of EGCG led to a reduction in PM, VSL, LIN, STR, and WOB, as well as higher ALH and percentage of gametes with intact plasma membrane at $0 \mathrm{~h}$ (Table 2 and 4).

\section{DISCUSSION}

The findings of the present study showed that the treatments with (+)-catechin or EGCG, at higher concentrations (50 to $100 \mu \mathrm{M})$, had an inhibitory effect on goat sperm kinematics, immediately after semen thawing. Thus, in a dose-dependent manner, (+)-catechin, especially, reduced the sperm velocity parameters (VSL and VAP), whereas EGCG inhibited the sperm progressive motility and LIN; parameters directly linked with fertility rates and the progression of sperm displacement (Matos et al., 2008). However, after $1 \mathrm{~h}$ of incubation, the kinematic parameters of the experimental groups in both experiments were similar, revealing the reversible character of catechin treatments.

Table 3. Plasma membrane, acrosome, morphology, and oxidative stress of goat semen frozen with different concentrations of $(+)$-catechin

\begin{tabular}{|c|c|c|c|c|c|c|c|c|c|c|}
\hline \multirow{3}{*}{ Parameters } & \multirow{3}{*}{ Time } & \multicolumn{6}{|c|}{ Concentrations of $(+)$-catechin } & \multirow{2}{*}{\multicolumn{3}{|c|}{$\begin{array}{c}\begin{array}{c}\text { Regression } \\
\text { assay* }\end{array} \\
\mathrm{P}>\mathrm{F} \\
\end{array}$}} \\
\hline & & \multirow[b]{2}{*}{$0 \mu \mathrm{M}$} & \multirow[b]{2}{*}{$15 \mu \mathrm{M}$} & \multirow[b]{2}{*}{$25 \mu \mathrm{M}$} & \multirow[b]{2}{*}{$50 \mu \mathrm{M}$} & \multirow[b]{2}{*}{$75 \mu \mathrm{M}$} & \multirow[b]{2}{*}{$100 \mu \mathrm{M}$} & & & \\
\hline & & & & & & & & $\mathrm{L}$ & $\mathrm{Q}$ & $\mathrm{C}$ \\
\hline PMi & $1 \mathrm{~h}$ & $28.1 \pm 6.7$ & $32.8 \pm 8.7$ & $34.0 \pm 7.3$ & $33.4 \pm 5.6$ & $37.2 \pm 12.2$ & $33.6 \pm 7.4$ & ns & ns & ns \\
\hline \multirow[t]{2}{*}{$\mathrm{ACi}$} & $\mathrm{Oh}$ & $50.9 \pm 9.3$ & $48.3 \pm 4.3$ & $48.8 \pm 4.3$ & $53.2 \pm 10.1$ & $52.5 \pm 5.5$ & $49.7 \pm 9.0$ & $\mathrm{~ns}$ & ns & ns \\
\hline & $1 \mathrm{~h}$ & $51.5 \pm 14.9$ & $48.5 \pm 10.6$ & $44.3 \pm 10.9$ & $50.8 \pm 13.8$ & $46.6 \pm 7.2$ & $48.9 \pm 7.3$ & ns & ns & ns \\
\hline nMOR & $1 \mathrm{~h}$ & $76.3 \pm 8.4$ & $74.9 \pm 3.1$ & $73.5 \pm 2.6$ & $76.6 \pm 5.3$ & $70.8 \pm 5.4$ & $75.2 \pm 1.8$ & ns & ns & ns \\
\hline \multirow[t]{2}{*}{$-\mathrm{OE}$} & $\mathrm{Oh}$ & $78.8 \pm 4.0$ & $81.2 \pm 4.9$ & $82.5 \pm 3.5$ & $83.0 \pm 3.4$ & $82.3 \pm 6.5$ & $82.3 \pm 4.3$ & $\mathrm{~ns}$ & ns & ns \\
\hline & $1 \mathrm{~h}$ & $76.3 \pm 4.8$ & $76.5 \pm 3.3$ & $75.2 \pm 5.1$ & $78.8 \pm 4.1$ & $77.0 \pm 4.5$ & $80.2 \pm 5.9$ & ns & ns & ns \\
\hline
\end{tabular}

PMi: plasma membrane integrity (\%); ACi: acrosome integrity (\%); nMOR: normal morphology (\%); -OS: negative oxidative stress (\%). *L: linear; Q: quadratic; C: cubic. 
Table 4.Plasma membrane, acrosome, morphology, and oxidative stress of goat semen frozen with different concentrations of EGCG

\begin{tabular}{|c|c|c|c|c|c|c|c|c|c|c|}
\hline \multirow{3}{*}{ Parameters } & \multirow{3}{*}{ Time } & \multicolumn{6}{|c|}{ Concentrations of EGCG } & \multirow{2}{*}{\multicolumn{3}{|c|}{$\begin{array}{c}\text { Regression assay* } \\
\mathrm{P}>\mathrm{F}\end{array}$}} \\
\hline & & \multirow[b]{2}{*}{$0 \mu \mathrm{M}$} & \multirow[b]{2}{*}{$15 \mu \mathrm{M}$} & \multirow[b]{2}{*}{$25 \mu \mathrm{M}$} & \multirow[b]{2}{*}{$50 \mu \mathrm{M}$} & \multirow[b]{2}{*}{$75 \mu \mathrm{M}$} & \multirow[b]{2}{*}{$100 \mu \mathrm{M}$} & & & \\
\hline & & & & & & & & $\mathrm{L}$ & $Q$ & $\mathrm{C}$ \\
\hline PMi & Oh & $39.3 \pm 4.7^{b}$ & $44.5 \pm 6.8^{\mathrm{ab}}$ & $41.0 \pm 5.5^{\mathrm{ab}}$ & $43.5 \pm 8.2^{\mathrm{ab}}$ & $43.3 \pm 4.2^{\mathrm{ab}}$ & $51.3 \pm 8.3^{\mathrm{a}}$ & 0.0117 & ns & ns \\
\hline \multirow[t]{2}{*}{$\mathrm{ACi}$} & $\mathrm{Oh}$ & $44.8 \pm 7.0$ & $45.1 \pm 8.1$ & $47.0 \pm 10.5$ & $46.0 \pm 6.6$ & $47.8 \pm 4.9$ & $49.7 \pm 7.6$ & ns & ns & ns \\
\hline & $1 \mathrm{~h}$ & $43.4 \pm 8.8$ & $42.7 \pm 11.8$ & $39.6 \pm 9.7$ & $42.1 \pm 10.2$ & $40.0 \pm 11.0$ & $42.1 \pm 9.8$ & ns & ns & ns \\
\hline nMOR & $\mathrm{Oh}$ & $86.6 \pm 5.3$ & $84.5 \pm 6.3$ & $84.5 \pm 6.8$ & $84.8 \pm 6.4$ & $87.5 \pm 1.8$ & $84.4 \pm 6.9$ & ns & ns & ns \\
\hline \multirow[t]{2}{*}{$-\mathrm{OE}$} & $\mathrm{Oh}$ & $78.5 \pm 3.5$ & $81.0 \pm 4.4$ & $82.3 \pm 2.8$ & $82.7 \pm 4.6$ & $81.3 \pm 4.0$ & $82.0 \pm 2.9$ & ns & ns & ns \\
\hline & $1 \mathrm{~h}$ & $74.0 \pm 2.9$ & $76.0 \pm 4.6$ & $78.7 \pm 4.7$ & $78.0 \pm 3.9$ & $78.8 \pm 2.2$ & $77.2 \pm 2.9$ & ns & ns & ns \\
\hline
\end{tabular}

Different letters in the same line denote significant differences between groups $(\mathrm{P}<0.05)$. PMi: plasma membrane integrity $(\%)$; ACi: acrosome integrity (\%); nMOR: normal morphology (\%); -OS: negative oxidative stress (\%). *L: linear; Q: quadratic; C: cubic.

Based on similar results, the use of EGCG at high concentrations is sometimes considered detrimental to sperm and linked to an increase in ROS production (De Amicis et al., 2012).Nevertheless, it is important to consider that the investigated catechins are inhibitors of F0F1-ATPase (Zheng and Ramirez, 2000) and cyclooxygenase (COX) (Kundu et al., 2003). FOF1-ATPase is an ATP synthase from mitochondria that represents one of the pathways to ATP synthesis (Zheng and Ramirez, 2000).Moreover, COX is a regulator of the prostaglandins production, which are modulators of sperm motility(Kennedy et al., 2003). In this way, catechins can be considered motility inhibitors by nature, in a dose-dependent response.

It is possible that the inhibitory effect of catechinson goat sperm kinematics occurred in a defensive manner. This hypothesis can be justified considering that the mitochondria are the main source of ROS in sperm (Koppers et al., 2008) and that their maximum activity occurs during the sperm capacitation (Ramio-Lluch et al., 2011). Moreover, COX is an enzyme linked to sperm capacitation and acrosome reaction (Joyce et al., 1987); events that can be induced prematurely during the cryopreservation process (Watson, 2000).

The treatment with (+)-catechin did not increase the percentage of cells with plasma membrane and acrosome integrity, normal morphology, or sperm without oxidative stress. However, the therapy with $100 \mu \mathrm{M}$ EGCG showed a powerful capacity to protect the plasma membrane integrity, immediately after thawing, evidencing a dose-dependent effect.No significant improvement was observed in the other parameters in Experiment 2; except for a tendency $(\mathrm{P}=0.07)$ of EGCG to maintain a greater number of cells without oxidative stress than the control group, $2 \mathrm{~h}$ after semen thawing (dates not shown).Therefore, it is probable that the absence of plasma membrane integrity increase, after $1 \mathrm{~h}$ incubation, was due to the removal of the cryopreservation stress factor, and not to loss of EGCG activity.

In opposition to these results, Boonsorn et al. (2010) observed a protective effect of (+)catechin $(25,50,75$, and $100 \mu \mathrm{M})$ on plasma membrane integrity and lipoperoxidation of cooled boar semen. Moreover, De Amicis et al. (2012) showed that the incubation of fresh human semen with EGCGatlow concentrations (2 and $20 \mu \mathrm{M}$ ) resulted in greater plasma membrane integrity than the control or a higher concentration $(60 \mu \mathrm{M})$; although in the present study, this was observed with $100 \mu \mathrm{M}$ EGCG. However, it is important to note that in the boar semen (Boonsorn et al., 2010), a chemically defined medium was used, and in the latter case (De Amicis et al., 2012), the semen samples were plasma free, diluted in a protein-free buffer, and maintained in a controlled atmosphere.

In the present study, although the seminal plasma had been removed, it was used with a milk-based extender with $\mathrm{pH} 6.8$ and the atmosphere was not controlled. However, catechins have an affinity toproteins, such as milk proteins, with which they can bind and form stable complexes (Hassan et al., 2013). Moreover, catechin stability decreases with the increase in $\mathrm{pH}(\mathrm{pH} 4$ to 8), resulting in their degradation (Zhu et al., 1997) and acquisition of a negative charge that is repulsed by the cell (Martínez-Flórez et al., 2002). It is possible that catechins also suffer 
oxidation when exposed to light and atmospheric oxygen (Nath et al., 2012). All these factors result in loss of catechin antioxidant activity (Nath et al., 2012; Hassan et al., 2013).

In addition, the decrease in somekinematic parameters has been associated with differences in extender density, viscosity, and number and size of particles (Tekin and Daşkin, 2016). This can justify the fact that, immediately post-thaw, the groups treated with the largest concentrations of polyphenols presented decreased VSL, VAP, and WOB in Experiment 1, without changes in other criteria, as well as decreased PM, LINand WOB in Experiment 2, associated with a higher PMi.

Despite reports about the dual role of EGCG (Martínez-Flórez et al., 2002; Weinreb et al., 2009), this flavonoid is considered the most powerful antioxidant among the catechins (Adela et al., 2010). Therefore, it is justifiable that the EGCG excelled over the (+)-catechin, despite the presence of some negative factors. In this context, there is a clear need for further studies on catechins in goat semen cryopreservation, taking into account the negative influences affecting this agent. Finding the appropriate conditions will enable the protective properties of catechins to bemaximized during goat semen cryopreservation.

\section{CONCLUSION}

Under the experimental conditions used, (+)catechin or EGCG at higher concentrations (50 to $100 \mu \mathrm{M}$ ) inhibits the sperm kinematics of frozen goat semen compared to low concentrations, in a transitory way over incubation time, and $100 \mu \mathrm{M}$ EGCG preserves the plasma membrane integrity of these gametes immediately after thawing.

\section{ACKNOWLEDGEMENTS}

The authors are grateful to FACEPE, CNPq, CAPES, and RENORBIO.

\section{REFERENCES}

ADELA, P.; DUMITRITA, R.; RALUCA, P. et al. Catechin-rich green tea extract modulates the oxidative status of human retinal pigment epithelial cells. Rom. Biotechnol. Lett., v.15, p.4964-4978, 2010.
BANSAL, A.K.; BILASPURI, G.S. Impacts of oxidative stress and antioxidants on semen functions. Vet. Med. Int., v.2011, p.1-7, 2011.

BARBAS, J.P.; MASCARENHAS, R.D. Cryopreservation of domestic animal sperm cells. Cell Tissue Bank., v.10, p.49-62, 2000.

BOONSORN, T.; KONGBUNTAD, W.; NARKKONG, N.A. et al. Effects of catechin addition to extender on sperm quality and lipid peroxidation in boar semen. Am. Eurasian J. Agric. Environ. Sci., v.7, p.283-288, 2010.

DE AMICIS, F.; SANTORO, M.; GUIDO, C. et al. Epigallocatechin gallate affects survival and metabolism of human sperm. Mol. Nutr. Food Res., v.56, p.1655-1664, 2012.

DING, J.; WANG, H.; WU, Z.B. et al. Protection of murine spermatogenesis against ionizing radiation-induced testicular injury by a green tea polyphenol. Biol. Reprod., v.92, p.1-13, 2015.

GU, J.W.; MAKEY, K.L.; TUCKER, K.B. et al. EGCG, a major green tea catechin suppresses breast tumor angiogenesis and growth via inhibiting the activation of HIF- $1 \alpha$ and NFkB, and VEGF expression. Vasc. Cell., v.5, p.1-10, 2013.

HASSAN, Z.M.R.; DIN, H.M.F.E.; ALI, A.A. et al. Interaction of some low molecular weight phenolics with milk proteins. World Appl. Sci. J., v.23, p.182-187, 2013.

HIRASAWA, M.; TAKADA, K. Multiple effects of green tea catechin on the antifungal activity of antimycotics against Candida albicans. J. Antimicrob. Chemother., v.53, p.225229, 2004.

JOYCE, C.L.; NUZZO, N.A.; WILSON JR, L. et al. Evidence for a role of Cyclooxygenase (Prostaglandin Synthetase) and prostaglandins in the sperm acrosome reaction and fertilization. $J$. Androl., v.8, p.74-82, 1987.

KENNEDY, J.H.; KORN, N.; THURSTON, R.J. Prostaglandin levels in seminal plasma and sperm extracts of the domestic turkey, and the effects of cyclooxygenase inhibitors on sperm mobility. Reprod. Biol. Endocrinol., v.1, p.1-7, 2003. 
KOPPERS, A.J.; DE IULIIS, G.N.; FINNIE, J.M. et al. Significance of mitochondrial reactive oxygen species in the generation of oxidative stress in spermatozoa. J. Clin. Endocrinol. Metabol., v.93, p.3199-3207, 2008.

KUNDU, J.K.; NA, H.K.; CHUN, K.S. et al. Inhibition of phorbol ester-induced COX-2 expression by epigallocatechin gallate in mouse skin and cultured human mammary epithelial cells. J. Nutr., v.133, p.3805S-3810S, 2003.

LEBOEUF, B.; RESTALL, B.; SALAMON, S. Production and storage of goat semen for artificial insemination. Anim. Reprod. Sci., v.62, p.113-141, 2000.

LI, Y. Antioxidants in biology and medicine: essentials, advances, and clinical applications. New York: Nova Science Publishers, 2011. 422p.

LOTITO, S.B.; FRAGA, C.G. Catechins delay lipid oxidation and $\alpha$-tocopherol and $\beta$-carotene depletion following ascorbate depletion in human plasma. Proc. Soc. Exp. Biol. Med., v.225, p.32-38, 2000.

MABE, K.; YAMADA, M.; OGUNI, I. et al. In vitro and in vivo activities of tea catechins against Helicobacter pylori. Antimicrobiol. Agents Chemother., v.43, p.1788-1791, 1999.

MARTÍNEZ-FLÓREZ, S.; GONZÁLEZGALLEGO, J.; CULEBRAS, J.M. et al. Los flavonoides: propiedades y acciones antioxidants. Nutr. Hosp., v.17, p.271-278, 2002.

MATOS, D.L.; ARAÚJO, A.A.; ROBERTO, I.G. et al. Análise computarizada de espermatozoides: revisão de literatura (Computer-assisted sperm analysis (CASA): a review). Rev. Bras. Reprod. Anim., v.32, p.225232, 2008.

NAGAO, T.; KOMINE, Y.; SOGA, S. et al. Ingestion of a tea rich in catechins leads to a reduction in body fat and malondialdehydemodified LDL in men. Am. J. Clin. Nutr., v.81, p.122-129, 2005.

NATH, S.; BACHANI, M.; HARSHAVARDHANA, D. et al. Catechins protect neurons against mitochondrial toxins and HIV proteins via activation of the BDNF pathway. J. Neurovirol., v.18, p.445-455, 2012.
OLIVEIRA, M.E.F.; SILVA, J.C.B. Andrologia. In: OLIVEIRA, M.E.F.; TEIXEIRA，P.P.M.; VICENTE, W.R.R. Biotécnicas reprodutivas em ovinos e caprinos. São Paulo: MedVet, 2013. p.35-60.

RAMIO-LLUCH, L.; FERNANDEZ-NOVELL, J.M.; PENA, A. et al. 'In vitro' capacitation and acrosome reaction are concomitant with specific changes in mitochondrial activity in boar sperm: evidence for a nucleated mitochondrial activation and for the existence of a capacitation-sensitive subpopulational structure. Reprod. Domest. Anim., v.46, p.664-673, 2011.

SALEH, R.A.; AGARWAL, A. Oxidative stress and male infertility: from research bench to clinical practice. J. Androl., v.23, p.737-752, 2002.

SILVA, E.C.B.; CAJUEIRO, J.F.P.; SILVA, S.V. et al. Effect of antioxidants resveratrol and quercetin on in vitro evaluation of frozen ram sperm. Theriogenology, v.77, p.1722-1726, 2012.

SONG, J.M.; LEE, K.H.; SEONG, B.L. Antiviral effect of catechins in green tea on influenza virus. Antiviral Res., v.68, p.66-74, 2005.

TEKIN, K.; DAŞKIN, A. Effect of different extenders on motility and some sperm kinematics parameters in Norduz goat semen. Turk. J. Vet. Anim. Sci., v.40, p.490-495, 2016.

WATSON, P.F. The causes of reduced fertility with cryopreserved. Anim. Reprod. Sci., v.60-61, p.481-492, 2000.

WEINREB, O.; AMIT, T.; MANDEL, S. et al. Neuroprotective molecular mechanisms of (-)epigallocatechin-3-gallate: a reflective outcome of its antioxidant, iron chelating and neuritogenic properties. Genes Nutr., v.4, p.283-496, 2009.

ZHENG, J.; RAMIREZ, V.D. Inhibition of mitochondrial proton F0F1-ATPase/ATP synthase by polyphenolic phytochemicals. $B r . J$. Pharmacol., v.130, p.1115-1123, 2000.

ZHU, Q.Y.; ZHANG, A.; TSANG, D. et al. Stability of green tea catechins. J. Agric. Food Chem., v.45, p.4624-4628, 1997. 